\title{
Pengaruh Kedisiplinan Guru dan Motivasi Belajar Siswa terhadap Peningkatan Prestasi Belajar Siswa di MI se-Kecamatan Wonodadi Kabupaten Blitar
}

\author{
Khoiruzzaim Kurniawan \\ Sekolah Tinggi Ilmu Syari'ah Faqih Asy'ari Kediri, Indonesia \\ e-mail: khoiruzzaimkurniawan@gmail.com
}

\begin{abstract}
The research in this thesis prompted by the weakening of discipline teachers who could be seen among others, it can be seen from teachers who skip their class/default teacher, teachers who late go to the class or school, teachers who have no learning or incomplete preparation and also the low student motivation. So the researcher wanted to examine the influence of the discipline of teachers and students' motivation to improve students 'achievement in the school.

The research method used in this research was quantitative in particularly survey research. As for the population in this research were all Elementary School (MI) students throughout Wonodadi sub-district, 18 schools. By using cluster sampling method, four schools were selected, consisting of 2638 students and 229 teachers. In this research, the number of samples was based on the table of samples determining number from specific populations developed by Issac and Michael by using standard error of $5 \%$ in a number of 307 students and 135 teachers. Data was collected by questionnaire instrument. Data analysis and hypothesis testing in this research used simple regression, multiple regression.

The results showed that (1) There was a positive and significant influence between the discipline and student achievement in Islamic Elementary School (MI) student achievement throughout Wonodadi subdistrict. (2) There was a positive and significant influence between learning motivation on student achievement (3) There was a positive and significant influence between discipline and learning motivation on student achievement
\end{abstract}

Keywords: Effect, Discipline, Motivation students, Student Achievement

\section{Pendahuluan}

Dalam proses pembelajaran banyak hal yang mempengaruhi prestasi belajar, peranan guru sebagai pelaksana perlu meningkatkan profesionalismenya dalam hal kegiatan belajar mengajar di sekolah terutama kedisiplinan dan memberikan motivasi kepada siswa. Dengan kata lain, kedisiplinan dan motivasi merupakan salah satu syarat agar prestasi belajar siswa di sekolah menjadi lebih baik. Selain itu kedisiplinan guru juga akan menjadi suatu rangsangan bagi siswa agar lebih disiplin dalam belajar.

Seorang guru profesional memiliki keahlian, keterampilan, dan kemampuan sebagaimana filosofi Ki Hajar Dewantara: "Tut wuri handayani, ing ngarso sung tulodo, ing madya mangun karso". Tidak cukup dengan menguasai materi pelajaran

\footnotetext{
${ }^{1}$ Martinis Yamin, Profesionalisasi Guru \& Implementasi KTSP, (Jakarta: Gaung Persada Press, 2011), h. 5.

2 Tulus Tu'u, Peran Disiplin pada Perilaku dan Prestasi Siswa, (Jakarta: PT. Raja Grafindo Persada, 2004), h. 4.
}

akan tetapi mengayomi murid, menjadi contoh atau teladan bagi murid serta selalu mendorong murid untuk lebih baik dan maju. ${ }^{1}$

Dalam mendidik disiplin berperan mempengaruhi, mendorong, mengendalikan, mengubah, membina dan perilaku-perilaku tertentu sesuai dengan nilai-nilai yang ditanamkan, diajarkan dan diteladani. ${ }^{2}$ Faktor lain yang dapat meningkatkan prestasi siswa adalah motivasi belajar. Seseorang yang termotivasi, ia akan berusaha berbuat sekuat tenaga untuk mewujudkan apa yang diinginkannya, sehingga tujuan dapat tercapai dan kepuasan dapat dirasakan. Motivasi belajar penting ditumbuhkan pada diri siswa baik motivasi yang bersifat intrinsik maupun ekstrinsik. ${ }^{3}$

Sondang berpendapat bahwa "Pengaruh motivasi siswa untuk meningkatkan prestasi belajar

\footnotetext{
${ }^{3}$ Indriyo Gitosudarmo, Perilaku Keorganisasian, (Yogyakarta: BPFE, 2001), h. 35.
} 
siswa sangat penting antara lain agar motivasi yang diharapkan merupakan setiap kegiatan yang mendorong, meningkatkan belajar dan mengajak siswa belajar lebih giat. Dengan motivasi dapat menimbulkan semangat belajar yang baik. Karena dalam bentuk pembinaan atau bimbingan tersebut dapat memotivasi setiap siswa dalam melakukan aktivitas dan target yang diharapkan". ${ }^{4}$

Keberhasilan seorang siswa dalam belajar dapat dilihat dari prestasi belajar siswa yang bersangkutan. Di dalam pendidikan siswa akan dinilai keberhasilannya melalui tes hasil belajar. Hasil yang diharapkan adalah prestasi belajar yang baik karena setiap orang menginginkan prestasi yang tinggi, baik siswa, guru, sekolah, maupun orang tua hingga masyarakat. Namun antara siswa satu dengan siswa yang lainnya berbeda dalam mencapai prestasi belajar. Ada yang mampu mencapai prestasi yang tinggi, namun ada juga siswa yang rendah prestasi belajarnya. $^{5}$

Oleh karena itu sebagai guru Madrasah Ibtidaiyah hendaknya mampu menjadi contoh serta tauladan yang baik pada anak didiknya, salah satunya yakni dengan kedisiplinan guru dalam mengajar serta memberi motivasi kepada siswa yang akan berdampak pada meningkatnya prestasi belajar siswa. ${ }^{6}$

Rendahnya tingkat kompetensi profesionalisme guru, penguasaan guru terhadap materi dan metode pengajaran yang masih berada di bawah standar, sebagai penyebab rendahnya mutu guru yang bermuara pada rendahnya citra guru. Berkaitan dengan ini Sugiyono menyatakan:

Rendahnya pengakuan masyarakat terhadap profesi guru yang mengakibatkan rendahnya citra guru disebabkan oleh faktor bahwasannya siapapun dapat menjadi guru asalkan ia berpengetahuan, banyak guru yang belum menghargai profesinya apalagi mengembangkan profesinya itu, perasaan rendah diri karena menjadi guru serta penyalahgunaan profesi untuk kepuasan dan kepentingan pribadinya. $^{7}$
Melihat realitas sekarang ini Ari Firmandi mengungkapkan bahwa:

Guru dipandang sebagai orang yang bertugas untuk memberikan pengajaran atau pelajaran kepada peserta didiknya dalam waktu tertentu dan dapat dinilai dengan materi. Tugas guru seakan dibatasi oleh ruang dan waktu ketika ia bertugas, sementara di luar itu adalah urusan pribadi. Peran guru hanya mengajar bukan mendidik. Tidak jarang guru hanya mengajari anak didiknya berperilaku baik sementara dirinya tidak demikian. Masyarakat sering mengeluh dan menuding guru tidak mampu mengajar manakala putra putrinya memperoleh nilai rendah, rangkingnya merosot. Akhirnya sebagian orang tua mengikutsertakan putra-putrinya untuk kursus, privat atau bimbingan belajar. ${ }^{8}$

Seorang guru biasanya selalu memberikan motivasi kepada peserta didik untuk belajar lebih giat lagi dan meningkatkan prestasi belajar mereka. Prestasi belajar merupakan hal yang ditunjukkan siswa setelah melakukan prestasi belajar mengajar. Prestasi belajar merupakan hasil yang ditunjukkan siswa setelah melakukan proses belajar mengajar. Prestasi belajar biasanya ditunjukkan dengan angka dan nilai sebagai laporan hasil belajar. Banyak sekali faktor yang mempengaruhi prestasi belajar siswa, baik faktor intern maupun ekstern siswa. Jadi selain kedisiplinan guru, prestasi belajar itu dapat ditingkatkan dengan adanya motivasi belajar yang dimiliki oleh siswa. Karena motivasi sangat mendukung sekali dalam peningkatan prestasi

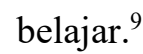

Citra guru terbentuk pada profesi yang melekat pada pribadi guru itu, bagaimana sikap keprofesionalannya dalam melaksanakan tugas dan kewajibannya. Citra guru akan dinilai baik oleh masyarakat apabila dapat menunjukkan kepada masyarakat bahwa ia layak menjadi panutan atau teladan masyarakat sekelilingnya. Masyarakat terutama akan melihat bagaimana sikap dan

\footnotetext{
${ }^{4}$ Sondang P. Siagian, Teori Motivasi dam Aplikasinya, (Jakarta: Rineka Cipta, 1995), h. 140.

${ }^{5}$ Slameto, Belajar dan Faktor yang Mempengaruhinya, (Jakarta: PT. Bina Aksara, 2003), h. 76.

${ }^{6}$ Said Ismail Ali, Pelopor Pendidikan IslamPaling Berpengaruh, (Jakarta: Alkautsar, 2010), h. 90.
}

${ }^{7}$ Sugiyono, Dasar-Dasar Ilmu Pendidikan, (Bandung: Alfabeta, 2008), h. 22.

8 Ari Firmandi, "Citra Guru Indonesia", dalam http://www.citraguruindonesia.go.id, diakses 3/3/2015.

9 Hasbullah Tabrani, Rahasia Sukses Belajar, (Jakarta: Raja Grafindo Persada, 1993), h. 98.

Jurnal Dirasah, Volume 1, Nomor 2, Agustus 2018 
perbuatan guru itu sehari-hari, apakah memang ada yang patut diteladani atau tidak. ${ }^{10}$

Salah satu faktor utama yang sangat berpengaruh dalam keberhasilan pembelajaran adalah keberadaan guru. Mengingat keberadaan guru dalam proses kegiatan belajar mengajar sangat berpengaruh, maka sudah semestinya kualitas guru harus diperhatikan. Sebagaimana telah dikemukakan di atas, bahwa dalam upaya meningkatkan mutu pendidikan, aspek utama yang ditentukan adalah kualitas guru. Untuk itu, upaya awal yang dilakukan dalam peningkatan mutu pendidikan adalah kualitas guru yang berbentuk disiplin kerja guru dan profesionalisme.

Disiplin kuat yang dimiliki guru, merupakan salah satu hal penting. Guru yang datang tepat waktu dan tidak meninggalkan kelas sebelum pelajaran berakhir adalah salah satu contoh yang dapat membangkitkan motivasi siswa dalam belajar. Tantangan dunia pendidikan pada zaman sekarang ini adalah tantangan bagi guru di dalam berhubungan dengan siswa dalam proses belajar mengajar. Di sini guru diharapkan dapat membangkitkan motivasi belajar, hasrat ingin tahu, dan minat yang kuat pada siswanya untuk mengikuti pelajaran di sekolah dan partisipasi aktif di dalamnya. Sebab semakin banyak yang aktif termotivasi untuk belajar maka semakin tinggi prestasi belajar yang diperolehnya.

Untuk menjamin terpeliharanya tata tertib dan kelancaran pelaksanaan tugas dalam mencapai tujuan sekolah, maka diperlukan guru yang penuh kesetiaan dan ketaatan pada peraturan yang berlaku dan sadar akan tanggung jawabnya untuk menyelenggarakan tujuan sekolah. Dengan kata lain kedisiplinan para guru sangat diperlukan dalam meningkatkan tujuan sekolah.

Untuk itu, menegakkan disiplin merupakan hal yang sangat penting, sebab dengan kedisiplinan dapat diketahui seberapa besar peraturan-peraturan dapat ditaati oleh guru. Dengan kedisiplinan di dalam mengajar guru proses pembelajaran akan terlaksana secara efektif dan efisien. Keberhasilan belajar siswa itu tidak terlepas dari keberhasilan proses belajar mengajar yang kemungkinan besar di pengaruhi oleh kedisiplinan guru.

${ }^{10}$ Tulus Tu'u, Peran Disiplin pada Perilaku dan Prestasi Siswa, (Jakarta: PT. Grasindo, 2004), h. 4.
Sekarang ini, guru di sekolah dituntut menjadi seorang panutan yang baik bagi siswanya, atau ia harus dapat memberikan contoh yang baik ketika mengajar sebagai cerminan bagi siswanya bagaimana berperilaku yang baik. Jadi ketika bertindak, siswa selalu berpatokan pada sikap atau perilaku di sekolah, bisa disimpulkan bahwa kedisiplinan dapat memotivasi siswa untuk belajar karena siswa biasanya akan mengikuti perilaku gurunya. Dengan adanya kesadaran diri untuk melaksanakan kedisiplinan di dalam mengajar, maka diharapkan semua kegiatan yang dilaksanakan sehari-hari dapat membuahkan hasil yang baik sesuai dengan tujuan yang telah ditetapkan.

Bagi guru yang disiplin, para siswa cenderung memberikan penghargaan lebih dalam bentuk perilaku siswa di sekolah. Misalnya kedisiplinan guru dalam bentuk tepat waktu hadir di sekolah juga diikuti oleh sebagian besar para siswa yang jarang terlambat hadir sekolah, begitu pula dalam peraturan penampilan yang diberlakukan bagi guru dan siswa yang harus tampil rapi serta akan dikenakan sanksi bagi yang melanggar peraturan tersebut, misalnya bagi guru diwajibkan berpakaian dan berpenampilan rapi sesuai seragam yang telah ditetapkan diikuti juga oleh para siswa khususnya menyangkut peraturan tidak diperbolehkan bagi siswa pria untuk memiliki rambut yang panjang. Oleh karena itu peran seorang guru sangat diperlukan dalam meningkatkan prestasi belajar siswa serta didukung oleh lingkungan dan tempat tinggal yang mendukung.

\section{Metode Penelitian}

\section{Pendekatan dan jenis penelitian}

Pendekatan penelitian yang digunakan dalam penelitian ini adalah kuantitatif. Penelitian kuantitatif adalah penelitian yang pada dasarnya menggunakan pendekatan deduktif, artinya pendekatan yang berangkat dari suatu kerangka teori, gagasan para ahli, maupun pemahaman peneliti berdasarkan pengalamannya, kemudian dikembangkan menjadi permasalahan beserta pemecahan yang diajukan untuk memperoleh pembenaran (verifikasi) dalam bentuk dukungan data empiris di lapangan. ${ }^{11}$

\footnotetext{
${ }^{11}$ Ahmad Tanzeh, Metodologi Penelitian,. h. 64-65.
} 
Metode yang digunakan dalam penelitian ini adalah metode survei. Menurut Singaribun dalam Andi Prastowo metode survey adalah penelitian yang mengambil sampel dari satu populasi dan menggunakan kuesioner sebagai alat pengumpul data pokok. ${ }^{12}$ Kuesioner atau angket ini digunakan dalam menganalisis besar kecilnya pengaruh kedisiplinan, motivasi belajar dan terhadap peningkatan prestasi belajar siswa di MI seKecamatan Wonodadi.

Penelitian ini termasuk pendekatan kuantitatif dengan menggunakan desain korelasional, penelitian ini ditujukan untuk mengetahui hubungan suatu variabel dengan variabel-variabel lain. Hubungan antara satu dengan beberapa variabel lain dinyatakan dengan besarnya koefisien korelasi dan keberartian (signifikansi) secara statistik. ${ }^{13}$ Dalam penelitian ini setiap variabel dicari korelasi (hubungannya), yakni antara variabel bebas (kedisiplinan guru, motivasi belajar siswa) terhadap variabel terikat (prestasi belajar siswa).

Populasi dan sampel penelitian

Populasi dalam penelitian ini adalah seluruh guru dan siswa MI Se- Kecamatan Wonodadi dengan jumlah 229 guru dan Siswa 2638 yang berada di 18 lembaga dengan 2 di MIN (Madrasah Ibtidaiyah Negeri) dan 16 di MIS (Madrasah Ibtidaiyah Swasta).

Tahap selanjutnya yaitu menentukan sampel daerah, dalam penelitian ini cakupan daerahnya yakni seluruh guru dan siswa di MI Se- Kecamatan Wonodadi yang terdiri dari 18 lembaga sekolah yang meliputi daerah:

1) Daerah utara terdiri dari guru dan siswa di 4 lembaga MI, yaitu: MHM Kebonagung, MI Assafiiyah Kebonangung danMI MINU Salam, MI Miftakhul Huda Tawangrejo.

2) Daerah timur terdiri dari guru dan siswa di 6 lembaga MI, yaitu: MI Darussalam Kolomayan, MIN Kolomayan, MI Nurul Jadid Kolomayan, MI Darussalam Pikatan, MI Darul Hikmah, dan MI Assafiiyah Pikatan,

\footnotetext{
12 Andi Prastowo, Memahami Metode- Metode Penelitian, (Jogjakarta, ar-ruzz Media, 2011), h. 176

${ }^{13}$ Nana Syaodiah Sukmadinata, Metode penelitian Pendidikan, (Bandung: Remaja Rosdakarya, 2009), h. 56.

${ }_{14}$ Menurut Sugiyono menyatakan bahwa probability sampling adalah teknik sampling yang memberikan peluang yang sama
}

3) Daerah barat terdiri dari guru dan siswa di 4 lembaga MI, yaitu: MI Darul Huda, MI Abu Naja Bakalan, MI Darul Ulum Rejosari dan MI Darussalam Wonodadi.

4) Daerah selatan terdiri dari guru dan siswa di 4 lembaga MI, yaitu: MIN Kunir, MI Fathul Huda Seduri, MI Wahid Hasyim 1 dan 2.

Dalam penelitian ini menggunakan Probability Sampling Secara skematis. ${ }^{14}$ Dan pada penelitian ini menggunakan Teknik cluster random sampling. Menurut Margono teknik ini digunakan bilamana populasi tidak terdiri dari individu-individu, melainkan terdiri dari kelompok-kelompok individu atau cluster. ${ }^{15}$ Teknik sampling daerah digunakan untuk menentukan sampel bila objek yang akan diteliti atau sumber data sangat luas, misalnya penduduk dari suatu negara, propinsi atau kabupaten. Untuk menentukan penduduk mana yang akan dijadikan sumber data, maka pengambilan sampelnya berdasarkan daerah populasi yang telah ditetapkan. ${ }^{16}$

Sugiyono memberikan contoh, di Indonesia terdapat 27 propinsi, dan sampelnya akan menggunakan 10 propinsi, maka pengambilan 10 propinsi itu dilakukan secara random. Tetapi perlu diingat, karena propinsi-propinsi di Indonesia itu berstrata maka pengambilan sampelnya perlu menggunakan stratified random sampling ${ }^{17}$. Contoh lainnya dikemukakan oleh Margono Ia mencotohkan bila penelitian dilakukan terhadap populai pelajar SMU di suatu kota. Untuk random tidak dilakukan langsung pada semua pelajar-pelajar, tetapi pada sekolah/kelas sebagai kelompok atau cluster. ${ }^{18}$

Peneliti memiliki keterbatasan biaya, waktu dan tenaga maka teknik sampling yang digunakan dalam penelitian ini adalah teknik cluster sampling. Teknik ini digunakan untuk menentukan sampel bila obyek yang akan diteliti atau sumber data sangat luas, misal penduduk dari suatu negara, provinsi atau kabupaten. Untuk menentukan penduduk mana yang akan dijadikan sumber data, maka pengambilan sampel ditetapkan secara bertahap dari wilayah yang luas

bagi setiap unsur (anggota) populasi untuk dipilih menjadi anggota sampel. Baca Sugiono. Metode Penelitian,., h. 57.

${ }^{15}$ Maryono. Metodologi Penelitian,. h. 127.

${ }^{16} \mathrm{Ibid}$,

${ }^{17}$ Sugiono, Metode Penelitian.., h. 59.

${ }^{18}$ Maryono, Metodologi Penelitian.., h. 127. 
(negara) sampai ke wilayah terkecil (kabupaten). Setelah terpilih sampel terkecil, kemudian baru dipilih sampel secara acak. Teknik sampling daerah ini sering digunakan melalui dua tahap, yaitu tahap pertama menentukan sampel daerah, dan tahap berikutnya menentukan orang- orang yang ada pada daerah itu secara sampling juga. ${ }^{19}$

Peneliti mengambil sampel ${ }^{20}$ sebagian populasi siswa dari keempat sekolah menjadi 307 siswa dan keseluruhan populasi guru ditambah dari beberapa guru di beberapa MI di kecamatan Wonodadi sehingga berjumlah 135 sampel.

Suharsimi Arikunto berpendapat, bahwa sampel digunakan untuk patokan prediksi apabila subjeknya kurang dari seratus (100), seyogyanya diambil semua sehingga penelitiannya merupakan penelitian populasi, sedangkan jika subjeknya besar dapat diambil antara $10-15 \%$ atau $20-25 \%$ atau lebih. ${ }^{21}$ Kemudian dipilih guru 67 dan siswa 307 dari 4 lembaga sekolah secara random sampling untuk mewakili sampel. Berikut keistimewaan sekolah yang dijadikan lokasi penelitian oleh peneliti:

1) Daerah Timur guru dan siswa di MI Darussalam Pikatan, merupakan lembaga pendidikan yang memiliki persaingan yang ketat antara yang satu dengan yang lain.

2) Daerah utara guru dan siswa di MI Assafiiyah Kebonagung, merupakan salah satu lembaga pendidikan yang memiliki tingkat kedisiplinan yang tinggi.

3) Daerah Barat guru dan siswa di MI Darul Huda, merupakan Madrasah yang berusaha mengembangkan budaya religious disetiap aspek pembelajaran.

4) Daerah selatan guru dan siswa di MIN Kunir, merupakan Madrasah unggulan di wilayah wonodadi dan letaknya strategis yakni berada di lingkungan pondok pesantren.

Dalam penelitian ini untuk menentukan jumlah sampel yang akan diambil peneliti mengambil

\footnotetext{
19 Sugiyono, Statiska untuk Penelitian, (Bandung: Alfabeta, 2013), h. 65-66.

${ }^{20}$ Sampel adalah sebagian atau wakil populasi yang diteliti. Sampel juga dapat didefinisikan sebagai suatu bagian yang ditarik dari populasi. Baca Arikunto, Prosedur Penelitian Suatu Pendekatan Praktik, (Jakarta: PT. Rineka Cipta, 2006), h. 174. Baca juga Istijianto M.M, Aplikasi Praktis Riset Pemasaran, (Jakarta: PT. Gramedia Pustaka Utama, 2005), h. 109.
}

jumlah sampel dengan taraf kesalahan 5\% yaitu 135 responden dari 299 populasi guru dan 307 dari 2635 populasi siswa yang ada. Hal ini berdasarkan tabel penentuan jumlah sampel dari populasi tertentu yang dikembangkan oleh Issac dan Michael. ${ }^{22}$.

Tabel penentuan jumlah sampel dari Isaac dan Michael memberikan kemudahan penentuan jumlah sampel berdasarkan tingkat kesalahan $1 \%, 5 \%$ dan $10 \%$. Dengan tabel ini, peneliti dapat secara langsung menentukan besaran sampel berdasarkan jumlah populasi dan tingkat kesalahan yang dikehendaki.

Adapun sampling yang digunakan oleh peneliti dalam menentukan sampel penelitian ini adalah Proporsional Random sampling. Pengambilan sampel dengan Proporsional Random sampling dilakukan dengan cara peneliti memilih responden secara acak tanpa memperhatikan prestasi siswa, keaktifan siswa, maupun cara belajar siswa. Untuk menentukan responden, peneliti hanya mengikuti instruksi dari guru pengampu mata di masing-masing lembaga sekolah MI pada waktu guru tersebut mengajar di dalam kelas. ${ }^{23}$ Apabila asumsi homogenitasnya terbukti maka peneliti dapat melakukan pada tahap analisis data lanjutan. ${ }^{24}$

\section{Instrumen penelitian}

Penelitian ini ada empat variabel, yaitu variabel kedisiplinan $\left(\mathrm{X}_{1}\right)$, motivasi belajar $\left(\mathrm{X}_{2}\right)$, dan prestasi belajar siswa $(\mathrm{Y})$. Dari tiap variabel dikembangkan menjadi butir- butir instrument melalui beberapa tahapan. Dalam penelitian ini digunakan instrument pengambilan data berupa angket. Instrument pengaruh kedisiplinan diukur dengan tiga sub variabel dan Lima belas indikator yang dikembangkan menjadi 26 butir item. Sebaran butir pernyataan di setiap sub variabel dan indikator pada angket tentang pengaruh kedisiplinan guru ini didasari pada teori Anwar Prabu Mangkunegara, yaitu pengaruh kedisiplinan guru ini dilaksanakan mulai Kedisiplinan disiplin preventif dan disiplin

\footnotetext{
${ }^{21}$ Suharsimi Arikunto, Prosedur Penelitian Suatu Pendekatan Praktek, (Yogyakarta: Rineka Cipta, 1999), h. 120.

${ }^{22}$ Sugiyono, Metode Penelitian Kuntitatif, Kualitatif dan R\&D, (Bandung: Alfabeta, 2011), h. 86-87.

${ }^{23}$ Suharsimi Arikunto, Prosedur Penelitian, Suatu Pendekatan Praktek Edisi Revisi Cet. 14, (Jakarta: Rineka Cipta, 2010), h. 175

${ }^{24}$ Tulus Winarsunu, Statistik dalam Penelitian Psikologi dan Pendidikan Cet. 3, (Malang: Univ. Muhammadiyah, 2006), h. 99.
} 
korelatif. Sedangkan instrumen motivasi belajar siswa diukur dengan empat sub variabel dan enam belas indikator yang dikembangkan menjadi 25 butir item. Sebaran butir pernyataan di setiap sub variabel pada angket tentang motivasi belajar siswa ini didasari pada pandangan peneliti.

Pada instrument prestasi belajar siswa, sebaran butir pernyataan di setiap sub variabel dan indikator pada test tentang prestasi belajar siswa ini didasari pada nilai semester II siswa, serta tentang beberapa indikasi terkait hasil proses belajar mengajar.

Bentuk angket pada penelitian ini tertutup dan menggunakan skala Likert dengan 4 alternatif jawaban yakni:

a. SR (Sering) diberi skor 4

b. KD (Kadang- Kadang) diberi skor 3

c. JR (Jarang) diberi skor 2

d. TP (Tidak Pernah) diberi skor 1

Sumber Data

Sumber data dalam penelitian adalah subjek dari mana data yang dapat diperoleh. ${ }^{25}$ Sumber data dalam penelitian ini dikelompokkan menjadi:

1. Sumber data primer

Sumber data primer adalah sumber pertama di mana sebuah data dihasilkan. ${ }^{26}$ Sumber data primer dalam penelitian ini adalah hasil penyebaran kuesioner atau angket dari sampel yang diambil.

2. Sumber data sekunder

Sumber data sekunder adalah sumber data kedua sesudah sumber data primer. Data yang dihasilkan dari sumber data ini adalah data sekunder. ${ }^{27}$ Data sekunder dalam penelitian ini adalah catatan-catatan lapangan oleh peneliti yang berupa dokumentasi, dan sebagainya yang dapat digunakan oleh peneliti untuk diproses lebih lanjut.

\section{Teknik pengumpulan data}

Dalam penelitian ini peneliti menggunakan angket untuk mencari data langsung dari para siswa yang peneliti ambil sebagai sampel. Angket merupakan teknik pengumpulan data yang dilakukan dengan cara memberi seperangkat pertanyaan atau pernyataan tertulis kepada responden untuk dijawab. Pengertian metode angket menurut Arikunto

\footnotetext{
${ }^{25}$ Suharsimi, Prosedur Penelitian ., h. 29.

${ }^{26}$ Burhan Bungin, Metodologi Penelitian Kuantatif, (Jakarta: Prenada Media, 2005), h. 29.

${ }^{27}$ Ibid., h. 129.
}

"Angket adalah pernyataan tertulis yang digunakan untuk memperoleh informasi dari responden dalam arti laporan tentang pribadi atau hal-hal yang ia ketahui". ${ }^{28}$

Angket atau kuesioner dibedakan menjadi dua macam: yaitu angket atau kuesioner dengan item pertanyaan secara terbuka dan angket atau kuesioner dengan pertanyaan tertutup. ${ }^{29}$ Dalam penelitian ini peneliti menggunakan angket atau kuesioner tertutup yaitu menyediakan beberapa alternatif jawaban, yang cocok bagi responden. Sehingga responden tinggal memilih dari jawaban yang ada yang paling mendekati pilihan responden.

Adapun pilihan yang disediakan terdiri dari 4 opsi atau 4 alternatif jawaban yang dapat dilihat dalam tabel 1 berikut skornya:

Tabel 1: Alternatif Jawaban Responden

\begin{tabular}{|c|c|c|}
\hline Opsi & Skor & Keterangan \\
\hline $\begin{array}{l}\text { Sering } \\
\text { (SR) }\end{array}$ & 4 & $\begin{array}{l}\text { Setiap kejadian yang digambarkan } \\
\text { pada pernyataan/pertanyaan itu } \\
\text { lebih banyak terjadi daripada tidak } \\
\text { terjadi }\end{array}$ \\
\hline $\begin{array}{l}\text { Kadang- } \\
\text { kadang } \\
(\mathrm{KK})\end{array}$ & 3 & $\begin{array}{l}\text { Setiap kejadian yang digambarkan } \\
\text { pada pernyataan/pertanyaan bisa } \\
\text { terjadi dan bisa tidak terjadi }\end{array}$ \\
\hline $\begin{array}{l}\text { Jarang } \\
\text { (JR) }\end{array}$ & 2 & $\begin{array}{l}\text { Setiap kejadian yang digambarkan } \\
\text { pada pernyataan/pertanyaan bisa } \\
\text { terjadi dan lebih sering tidak terjadi }\end{array}$ \\
\hline $\begin{array}{l}\text { Tidak } \\
\text { pernah } \\
\text { (TP) }\end{array}$ & 1 & $\begin{array}{l}\text { Setiap kejadian yang digambarkan } \\
\text { pada pernyataan/pertanyaan tidak } \\
\text { pernah terjadi }\end{array}$ \\
\hline
\end{tabular}

Semakin tinggi skor yang diperoleh dari angket maka akan semakin baik keadaan yang bersangkutan pada variabel $\mathrm{X}$ dan Y. Begitu pula sebaliknya, semakin rendah skor yang diperoleh maka akan semakin buruk keadaan yang bersangkutan pada variabel $\mathrm{X}$ dan $\mathrm{Y}$.

Selain angket, dalam pengumpulan data, peneliti juga menggunakan teknik observasi. Observasi merupakan suatu proses yang kompleks, suatu proses yang tersusun dari berbagai proses biologis dan psikologis. Dua di antara yang terpenting adalah proses-proses pengamatan dan ingatan. Menurut Sutrisno Hadi observasi adalah:

\footnotetext{
${ }^{28}$ Suharsimi. Prosedur Penelitian ..., h.151

${ }^{29}$ Sukardi, Metodologi Penelitian Pendidikan, (Jakarta:PT. Bumi Aksara, 2004), h. 77 .
} 
"Suatu teknik yang digunakan melalui pengamatan dan pencatatan secara sistematis terhadap fenomena yang diselidiki". ${ }^{30}$

Observasi yang peneliti lakukan adalah observasi langsung yakni dengan mengadakan pengamatan ke lokasi penelitian, yakni mencari data. Teknik analisis data

Setelah data terkumpul, peneliti melakukan analisis atau mengolah data yang diperoleh agar dapat digunakan untuk menjawab permasalahan yang telah diajukan. Ada dua tahapan dalam mengolah data, yaitu:

a. Tahap pertama (pengolahan data)

1) Editing, sebelum data diolah, data tersebut perlu diedit atau dengan kata lain data yang telah dikumpulkan dalam record book, daftar pertanyaan atau interview guide perlu dibaca sekali lagi dan diperbaiki jika ada kesalahan. ${ }^{31}$

2) Coding, yaitu pemberian kode-kode pada tiaptiap data yang termasuk dalam kategori yang sama. Kode adalah isyarat yang dibuat dalam bentuk angka/huruf yang memberikan petunjuk atau identitas pada suatu informasi atau data yang akan dianalisis. ${ }^{32}$ Maksud dari pemberian kode dalam penelitian ini adalah angket yang telah diperiksa, diberi identitas sehingga dapat diketahui kelanjutan proses pengolahan data. Hasil dari coding dalam penelitian ini sebagai berikut:

a. Untuk variabel independen (X), yaitu: kedisiplinan guruX $_{1}$, motivasi belajar siswa $\mathrm{X}_{2}$.

b. Untuk variabel dependen (Y), yaitu prestasi belajar siswa.

3) Tabulasi, yaitu memasukkan data ke dalam tabel-tabel dan mengatur angka-angka sehingga dapat dihitung jumlah kasus dalam beberapa kategori.

4) Penerapan data sesuai dengan pendekatan penelitian, yaitu pengolahan data dengan menggunakan rumus-rumus yang ada sesuai dengan pendekatan penelitian yang diambil. Setelah data diolah dan dimasukkan ke dalam tabel, selanjutnya adalah menganalisis atau

\footnotetext{
30 Sutrisno Hadi, Metodologi Research Jilid II, (Yogyakarta: Andi Offset, 1998), h. 136.

${ }^{31}$ Moh. Nazir, Metodologi penelitian (Bogor: Ghalia Indonesia, 2005), h. 346-355.
}

menguji data tersebut dengan analisis kuantitatif atau statistik.

b. Tahap kedua (Analisis data)

1) Deskripsi Data, langkah-langkah yang ditempuh adalah menyiapkan data, yaitu data tentang pengaruh kedisiplinan, motivasi belajar dan terhadap peningkatan prestasi belajar siswa di MI se-Kecamatan Wonodadi. Analisis deskriptif dalam penelitian ini menggunakan penilaian absolut yaitu norma yang ditetapkan secara mutlak oleh pembuat instrumen masing- masing item serta presentase pilihan yang diisyaratkan penetapan kriteria skor masing-masing variabel. Instrumen yang digunakan untuk mengukur variabel $\mathrm{X}_{1}$ terdiri dari 26 item soal, $\mathrm{X}_{2}$ terdiri dari 25 item soal, dan $\mathrm{Y}$ terdiri dari 23 soal yang masing- masing item soal diberi 5 alternatif jawaban dengan rentang skor 1-5.

2) Tahap pengujian persyaratan, sebelum dilakukan analisis data pengujian hipotesis dilakukan, terlebih dahulu dilakukan analisis prasyarat atau uji asumsi klasik yang meliputi:

a) Uji validitas, uji validitas yang dipakai adalah validitas internal. Untuk menguji validitas tiap item instrument adalah dengan mengkorelasikan antara skor-skor tiap item dengan skor total keseluruhan instrument dengan menggunakan rumus product moment. Item dikatakan valid, jikar $_{\text {hit }}>\mathrm{r}_{\text {tab }}$ dan sebaliknya. ${ }^{33}$ Untuk mengetahui validitas instrument pada penelitian ini, digunakan program SPSS 16.0 for windows.

b) Uji reliabilitas, uji reliabilitas yang dipakai adalah reliabilitas internal, yaitu menganalisis data dari satu kali hasil uji. Tehnik yang dipakai antara lain adalah tehnik belah dua (split-half-method) dengan rumus Spearman-Brown:

$$
r_{x x}=\frac{2 x r_{x y}}{1+r_{x y}}
$$

Caranya terlebih dahulu angket dibagi menjadi dua bagian, misalnya ganjil
32 Iqbal Hasan, Analisis Data Penelitian dengan Statistik (Jakarta: PT. Bumi Aksara, 2006), h. 24.

${ }^{33}$ Anas Sudijono, Statistik Pendidikan (Jakarta: PT Raja Grafindo Persada, 1987), h. 190-195. 
dan genap. $^{34}$ Setelah itu dilakukan perhitungan dengan SPSS 16.0 for windows.

c) Uji normalitas, pengujian ini bermaksud untuk mengetahui normal tidaknya data yang diperoleh. Hal ini dilakukan untuk menentukan statistik yang akan digunakan dalam mengolah data dan yang paling utama untuk menentukan apakah menggunakan statistic parametrik atau non parametrik sehingga langkah selanjutnya tidak menyimpang dari kebenaran dan dapat dipertanggungjawabkan. Uji normalitas dilakukan dengan menggunakan uji kolmogorov-smirnov satu sampel dengan SPSS16.0 for windows, untuk menguji normalitas. Jika probabilitas $>0,05$ maka datanya dikatakan berdistribusi normal, sebaliknya jika nilai probabilitasnya $<0,05$ maka datanya dinyatakan berdistribusi tidak normal. ${ }^{35}$

d) Uji linearitas, Secara umum uji liniaritas bertujuan untuk mengetahui apakah dua variable mempunyai hubungan yang linier secara signifikan atau tidak. Data yang baik seharusnya terdapat hubungan yang liniear antara variable predictor (X) dengan variable kriterium $(\mathrm{Y})$. Dalam penelitian ini data di uji liniaritas menggunakan SPSS16.0 for windows. Dasar pengambilan keputusan dalam uji linieritas dapat dilakukan dengan dua cara yakni pertama jika nilai sig. lebih besar 0,05 , maka kesimpulannya adalah terdapat hubungan linier secara signifikan antara variable $\mathrm{X}$ dengan variable $Y$. sebaliknya jika nilai sig. lebih kecil dari 0,05, maka kesimpulannya adalah tidak terdapat hubungan yang linear antara variable $\mathrm{X}$ dengan variable $\mathrm{Y}$. Kedua, adalah dengan melihat nilai $\mathrm{F}$ hitung dan $\mathrm{F}$ tabel, jika nilai $\mathrm{F}$ hitung lebih kecil dari $\mathrm{F}$ tabel maka kesimpulannya adalah terdapat hubungan linear secara signifikan antara variable $\mathrm{X}$

\footnotetext{
${ }^{34}$ Gunawan Sudarmanto, Analisis Regresi Linear Ganda dengan SPSS (Yogyakarta: Graha Ilmu, 2005), h. 89-99.

${ }^{35}$ Dwi Priyatno, Teknik Mudah dan Cepat dalam Melakukan Analisis data dengan SPSS, (Yogyakarta: Gava Media 2010), h. 129.
}

dengan variable Y. sebaliknya, jika nilai $\mathrm{F}$ hitung lebih besar dari $F$ tabel maka kesimpulannya tidak terdapat hubungan linier antara variable $\mathrm{X}$ dengan variable $\mathrm{Y}$.

e) Uji multikolonieritas, uji asumsi dasar ini diterapkan untuk analisis regresi yang terdiri atas dua atau lebih variabel di mana akan diukur tingkat asosiasi (keeratan) hubungan atau pengaruh antar variabel melalui besaran koefisien korelasi (r). Dikatakan multikolieritas jika koefisien korelasi antar variabel bebas (X) lebih besar dari 0.05 . dikatakan tidak terjadi multikolinieritas jika koefisien korelasi antar variabel bebas lebih kecil atau sama dengan $0.05 .^{36}$

f) Uji Heteroskedastisitas, uji ini digunakan untuk menguji apakah dalam model regresi terjadi ketidaksamaan varian dari model residual pada suatu pengamatan ke pengamatan yang lain. Model regresi yang baik adalah homokedastik atau tidak terjadi heteroskedastik. Hal demikian sering terjadi pada data yang bersifat cross section yaitu data yang dihasilkan pada suatu waktu dengan responden yang banyak. Heteroskedatisitas menguji terjadinya perbedaan variance residual suatu periode pengamatan ke periode pengamatan yang lain. Model regresi yang baik adalah model regresi yang memiliki persamaan variance residual suatu periode pengamatan dengan periode pengamatan yang lain sehingga dapat dikatakan model tersebut homokedastisitas dengan uji Spearman. Heteroskedastisitas dengan uji Spearman dapat diketahui dari nilai variabel Unstandarized Residual, jika nilainya lebih besar dari 0,05 maka bias dikatakan bahwa model regresi ini bebas dari heteroskedastisitas. ${ }^{37}$

g) Uji homogenitas, uji ini dilakukan untuk mengetahui apakah variansi antara kelompok yang diuji berbeda atau tidak,

\footnotetext{
36 Danang Sunyoto dan Ari Setiawan, Buku Ajar Statistik, (Yogyakarta: Nuha Medika, 2013), h. 153.

${ }^{37}$ Ibid., h. 154.
} 
variansinya homogeny atau heterogen. Data yang diharapkan adalah homogeny. Dalam penelitian ini data di uji homogenitas menggunakan One-Way ANOVA dengan SPSS16.0 for windows. ${ }^{38}$ Untuk mendapatkan data yang akurat maka instrument angket yang dipakai harus diuji validitas dan reliabilitas. Uji validitas digunakan untuk mendapatkan validitas yang tinggi dari instrumen, sehingga bisa memenuhi persyaratan. Sedangkan uji reliabilitas dilakukan guna memperoleh gambaran yang tetap mengenai apa yang diukur.

h) Analisis Inferensial (Tahap Pengujian Hipotesis) Penelitian ini menggunakan rumus regresi sederhana dan regresi ganda. Regresi sederhana didasarkan pada hubungan fungsional ataupun kausal satu variabel independen dengan satu variabel dependen. ${ }^{39}$ Sedangkan analisis regresi ganda merupakan pengembangan dari analisis regresi sederhana. Kegunaannya yaitu untuk meramalkan nilai variabel terikat (Y) apabila variabel bebasnya (X) dua atau lebih. ${ }^{40}$ Untuk memudahkan analisis regresi sederhana maka peneliti menggunakan perhitungan dengan SPSS 16.0 for windows. Tingkat signifikan ditentukan dengan $\alpha=5 \%$. Perlu diketahui bahwa besaran yang sering digunakan dalam penelitian non eksakta untuk menentukan taraf nyata adalah $1 \%, 5 \%$, $10 \%{ }^{41}$ Untuk menguji koefisien regresi secara simultan digunakan Uji F. Uji F dilakukan untuk mengetahui ada tidaknya pengaruh variabel bebas secara bersamasama terhadap variabel terikat.

\section{Temuan Penelitian dan Pembahasan}

Pengaruh kedisiplinan terhadap prestasi belajar siswa

Ada pengaruh yang positif dan signifikan antara kedisiplinan terhadap prestasi belajar siswa di MI se-
Kecamatan Wonodadi yang ditunjukkan dari $t_{\text {hitung }}>$ $t_{\text {tabel }}(127,173>1,968)$. Nilai signifikansi $t$ untuk variabel kedisiplinan adalah 0.000 dan nilai tersebut lebih kecil dari pada probabilitas $0.05(0,000<0,05)$. Sehingga dalam pengujian ini menunjukkan bahwa $\mathrm{H}_{\mathrm{a}}$ diterima dan $\mathrm{H}_{\mathrm{o}}$ ditolak. Dari tabel model Summary, nilai $\mathrm{R}^{2}=0,997$, artinya variabel bebas kedisiplinan mampu menerangkan atau memprediksi nilai variabel terikat prestasi belajar siswa sebesar $99,7 \%$. Hal ini berarti bahwa terjadi hubungan yang tinggi antara kedisiplinan terhadap prestasi belajar siswa. Serta ada pengaruh yang signifikan antara kedisiplinan $\left(\mathrm{X}_{1}\right)$ terhadap prestasi belajar siswa $(\mathrm{Y})$ di MI se-Kecamatan Wonodadi.

Hal ini berdasarkan pada teori Anwar Prabu Mangkunegara ia membagi disiplin dalam dua macam disiplin kerja, yaitu disiplin preventif dan disiplin korektif:

1) Disiplin preventif adalah suatu upaya untuk menggerakkan pegawai mengikuti dan memenuhi pedoman kerja, aturan-aturan yang telah digariskan oleh perusahaan. Tujuan dasarnya adalah untuk menggerakkan pegawai berdisiplin diri. Dengan cara preventif, pegawai dapat memelihara dirinya terhadap peraturan-peraturan perusahaan.

2) Disiplin korektif adalah suatu upaya menggerakkan perbagai dalam menyatukan suatu peraturan dan mengarahkan untuk tetap memenuhi peraturan sesuai dengan pedoman yang berlaku pada perusahaan.

Pada disiplin korektif, pegawai yang melanggar disiplin perlu diberikan sanksi sesuai peraturan yang berlaku. Tujuan pemberian sanksi adalah untuk memperbaiki pegawai, pelanggar, memelihara peraturan yang berlaku, dan memberikan pelajaran bagi pelanggar.

Kedua macam disiplin baik preventif dan korektif adalah disiplin diri guna melatih dan membentuk pribadi guru, murid dan staf agar bertanggung jawab terhadap kerja dan patuh kepada aturan (kebijakan) sekolah. Preventif ditujukan untuk mendorong para guru, murid dan staf mengikuti atau mematuhi norma-norma dan aturan-

\footnotetext{
40 Riduwan, Metode Dan Teknik Menyusun Tesis (Bandung: Alfabeta, 2006), h. 152.

${ }^{41}$ Ibid., 54.

${ }^{38}$ Muhammad Nisfiannoor, Pendekatan Statistik Modern Untuk Ilmu Sosial (Jakarta: Salemba Humanika, 2009), h. 91-103.

${ }^{39}$ Sugiyono, Statiska untuk Penelitian..., h. 261.
} 
aturan sekolah sehingga pelanggaran tidak terjadi. disiplin korektif ditujukan untuk memperkecil kemungkinan pelanggaran-pelanggaran lebih lanjut dengan diberikan sanksi yang tepat pada setiap pelanggaran yang terjadi.

Menurut Anwar Prabu Mangkunegara bahwasannya disiplin sangat penting karena alasan berikut ini:

1. Dengan disiplin yang muncul karena kesadaran diri siswa berhasil dalam belajarnya. Sebaliknya siswa yang sering kali melanggar ketentuan sekolah pada umumnya terhambat optimalisasi potensi dan prestasinya.

2. Tanpa disiplin guru yang baik, suasana sekolah dan juga kelas menjadi kurang kondusif bagi kegiatan pembelajaran. Secara positif disiplin memberi dukungan yang tenang dan tertib bagi proses pembelajaran.

3. Orang tua senantiasa berharap di sekolah anakanak dibiasakan dengan norma-norma, nilai kehidupan dan disiplin. Dengan demikian anakanak dapat menjadi individu yang tertib, teratur dan disiplin.

4. Disiplin guru merupakan jalan bagi siswa untuk sukses dalam belajar.

Disiplin sangat diperlukan terutama seorang siswa. Jika seorang siswa mempunyai kesadaran pentingnya disiplin, maka akan berhasil dalam belajarnya karena dalam proses belajar mengajar disiplin sangat mendukung keberhasilan dan kesuksesan. $^{42}$

Menurut teori Piet A. Sahertian disiplin dibagi ke dalam tiga bentuk seperti di bawah ini:

a. Disiplin tradisional, adalah disiplin yang bersifat menekan, menghukum, mengawasi, memaksa dan akibatnya merusak penilaian yang terdidik.

b. Disiplin modern, pendidikan hanya menciptakan situasi yang memungkinkan agar si pendidik dapat mengatur dirinya. Jadi situasi yang akrab, hangat, bebas dari rasa takut sehingga si terdidik mengembangkan kemampuan dirinya.

c. Disiplin liberal, yang dimaksud disiplin liberal, adalah disiplin yang diberikan sehingga anak merasa memiliki kebebasan tanpa batas. ${ }^{43}$

\footnotetext{
${ }^{42}$ Anwar Prabu Mangkunegara, Manajemen Sumber Daya Manusia Perusahaan, (Bandung: Remaja Rosdakarya, 2002 ), h. 129.

${ }^{43}$ Piet A. Sahertian, ...h.127
}

Menurut teori Zakiyah Drajat sebagaimana dikutip dalam buku Fikih pendidikan karya Heri Jauhari Muchtar merinci tugas guru atau pendidik dalam mengajar adalah: ${ }^{44}$

a. Menjaga proses belajar dan mengajar dalam suatu kesatuan.

b. Mengajar anak dalam berbagai aspek yaitu pengetahuan, keterampilan dan pengembangan seluruh kepribadian.

c. Mengajar sesuai tingkat perkembangan dan kematangan anak.

d. Menjaga keperluan (kebutuhan) dan bakat anak didik.

e. Menentukan tujuan-tujuan pelajaran bersamasama dengan anak atau peserta didik supaya mereka juga mengetahui dan mendukung pencapaian tujuan tersebut.

f. Memberi dorongan, penghargaan dan imbalan kepada peserta didik.

g. Menjadikan materi dan metode pengajaran berhubungan dengan kehidupan nyata, sehingga mereka menyadari bahwa yang dipelajarinya itu baik dan berguna.

h. Membagi materi pelajaran kepada satuan-satuan dan memusatkannya pada permasalahanpermasalahan.

i. Menghindari perbuatan-perbuatan yang percuma dan memberi informasi yang tak berarti, serta menjauhi hukuman dan pengulangan pekerjaan.

j. Mengikutsertakan anak atau peserta didik dalam PBM secara aktif sesuai dengan kemampuan dan bakatnya.

k. Warnai situasi proses belajar-mengajar dengan suasana toleran, kehangatan, persaudaraan dan tolong menolong. Suasana PBM tidak hanya berpengaruh terhadap keberhasilan pelajaran, tetapi juga mempunyai pengaruh dalam penyerapan anak atau peserta didik terhadap sifatsifat sosial yang baik atau tidak baik. ${ }^{45}$

Jadi ketika seorang guru memiliki kedisiplinan yang tinggi maka pembelajaran pun akan menjadi optimal, sehingga berdampak kepada meningkatnya prestasi belajar. Jika hal tersebut di atas bisa dilakukan dengan baik dan maksimal, maka

\footnotetext{
${ }^{44}$ Heri Jauhari Muchtar, Fikih, (Bandung: Remaja Rosdakarya, 2007), h. 155.

${ }^{45}$ Ibid., h. 156.
} 
bisa memberikan pengaruh yang positif dan signifikan bagi prestasi siswa.

Pengaruh motivasi belajar terhadap prestasi belajar siswa di MI se-Kecamatan Wonodadi

Ada pengaruh yang positif dan signifikan antara motivasi belajar terhadap prestasi belajar siswa di MI se-Kecamatan Wonodadi yang ditunjukkan dari $t_{\text {hitung }}>t_{\text {tabel }}(158,297>1,968)$. Nilai signifikansi $\mathrm{t}$ untuk variabel pengalaman mengajar adalah 0.000 dan nilai tersebut lebih kecil daripada probabilitas $0.05(0,000<0,05)$. Sehingga dalam pengujian ini menunjukkan bahwa $\mathrm{H}_{\mathrm{a}}$ diterima dan $\mathrm{H}_{\mathrm{o}}$ ditolak. Dari tabel model Summary, nilai $\mathrm{R}^{2}$ $=0,997$ artinya variabel bebas Motivasi Belajar mampu menerangkan atau memprediksi nilai variabel terikat prestasi belajar siswa sebesar 99,7\%. Hal ini berarti bahwa terjadi hubungan yang signifikan antara Motivasi Belajar terhadap prestasi belajar siswa. Serta ada pengaruh yang signifikan antara motivasi belajar $\left(\mathrm{X}_{2}\right)$ terhadap prestasi belajar siswa (Y) di MI se-Kecamatan Wonodadi.

Pengaruh kedisiplinan dan motivasi belajar terhadap prestasi belajar siswa di MI se-Kecamatan Wonodadi

Ada pengaruh yang positif dan signifikan antara kedisiplinan guru dan Motivasi Belajar terhadap Prestasi Belajar Siswa di MI se Kecamatan Wonodadi yang ditunjukkan dari $\mathrm{f}_{\text {hitung }}>\mathrm{f}_{\text {tabel }}$ $(25,514>3,060)$. Nilai signifikansi f untuk variabel kedisiplinan dan motivasi belajar adalah 0.000 dan nilai tersebut lebih kecil daripada probabilitas 0.05 $(0,000<0,05)$. Sehingga dalam pengujian ini menunjukkan bahwa $\mathrm{H}_{\mathrm{a}}$ diterima dan $\mathrm{H}_{\mathrm{o}}$ ditolak. Dari tabel model Summary, nilai $\mathrm{R}^{2}=0,997$ artinya variabel bebas kedisiplinan dan motivasi belajar mampu menerangkan atau memprediksi nilai variabel terikat prestasi belajar siswa sebesar 99,7\%, Hal ini berarti bahwa terjadi hubungan yang tinggi antara kedisiplinan dan motivasi belajar dengan prestasi belajar. Hal ini berdasarkan pada teori Anwar Prabu Mangkunegara yakni Kedua macam disiplin baik preventif dan korektif adalah disiplin diri guna melatih dan membentuk pribadi guru, murid dan staf agar bertanggung jawab terhadap

\footnotetext{
${ }^{46}$ Anwar Prabu, Manajemen Sumber., h.130.

${ }^{47}$ Hamzah B. Uno, Profesi Kependidikan. Jakarta: PT. Bumi Aksara 2008, h. 66-67.
}

kerja dan patuh kepada aturan (kebijakan) sekolah. Preventif ditujukan untuk mendorong para guru, murid dan staf mengikuti atau mematuhi normanorma dan aturan-aturan sekolah sehingga pelanggaran tidak terjadi. Disiplin korektif ditujukan untuk memperkecil kemungkinan pelanggaranpelanggaran lebih lanjut dengan diberikan sanksi yang tepat pada setiap pelanggaran yang terjadi. ${ }^{46}$

Sebagaimana dikemukakan oleh Glickman melalui penelitiannya menyimpulkan bahwa guruguru yang tingkatan nalarnya tinggi dapat melihat berbagai alternatif model mengajar sehingga mereka umumnya konsekuen dan efektif dalam menghadapi siswa. Dengan modal motivasi belajar menggunakan nalar ini, guru bisa melihat sesuatu dari berbagai perspektif. Sebaliknya apabila tingkat nalarnya rendah, hanya mampu menemukan salah satu alternatif saja. Akibatnya, guru merasa bingung ketika menghadapi masalah-masalah dalam kelas, dan tidak berbuat banyak. Oleh karena itu, mereka cenderung meminta petunjuk dalam melakukan tugas. ${ }^{47}$ Syafruddin Nurdin bahwasannya Mengajar atau lebih spesifik lagi melaksanakan proses belajar mengajar bukanlah suatu pekerjaan yang mudah dan dapat terjadi begitu saja tanpa direncanakan sebelumnya, akan tetapi mengajar itu merupakan suatu kegiatan yang semestinya direncanakan dan di desain sedemikian rupa mengikuti langkah-langkah dan prosedur tertentu, sehingga dengan demikian pelaksanaannya dapat mencapai hasil yang diharapkan.

Menurut teori E. Mulyasa bahwa Tugas guru dalam pembelajaran tidak terbatas pada penyampaian materi pembelajaran, tetapi lebih dari itu, guru harus membentuk motivasi belajar dan pribadi peserta didik, terutama pada jam-jam sekolah, agar tidak terjadi penyimpangan perilaku atau tindakan yang indisipliner. Untuk kepentingan tersebut, dalam rangka mendisiplinkan peserta didik guru harus mampu menjadi pembimbing, contoh atau teladan, pengawas dan pengendali seluruh perilaku peserta didik. ${ }^{48}$

Sebagai pembimbing guru harus berupaya untuk membimbing dan mengarahkan perilaku

\footnotetext{
${ }^{48}$ E. Mulyasa, Standar Motivasi belajar dan Sertifikasi Guru, (Bandung: Remaja Rosdakarya, 2007), h. 126.
} 
peserta didik ke arah yang positif, dan menunjang pembelajaran. Sebagai contoh atau teladan, guru harus memperlihatkan perilaku disiplin yang baik kepada peserta didik, karena bagaimana peserta didik akan berdisiplin sedangkan gurunya tidak menunjukkan sikap disiplin. Sebagai pengawas, guru harus senantiasa mengawasi seluruh perilaku peserta didik, terutama pada jam-jam efektif sekolah, sehingga kalau terjadi pelanggaran terhadap disiplin, dapat segera diatasi. Sebagai pengendali, guru harus mampu mengendalikan seluruh perilaku peserta didik disekolah. Dalam hal ini guru harus mampu secara efektif menggunakan alat pendidikan secara tepat waktu dan tepat sasaran, baik dalam memberikan hadiah maupun hukuman terhadap peserta didik. $^{49}$

Mengajar merupakan pekerjaan dan tugas yang kompleks dan sulit. Oleh karena itu tugas dan pekerjaan tersebut memerlukan persiapan dan perencanaan yang baik, sehingga dapat mencapai hasil yang diharapkan. Mengajar merupakan tugas yang perlu dipertanggungjawabkan. Dengan demikian ia memerlukan sesuatu perencanaan dan persiapan yang mantap dan dapat dinilai pada akhir kegiatan proses belajar mengajar. ${ }^{50}$

Ketika seorang guru memiliki kedisiplinan yang tinggi maka pembelajaran pun akan menjadi optimal, sehingga berdampak kepada meningkatnya prestasi belajar. Dan Semakin tinggi jenjang pendidikan seorang guru maka semakin tinggi pula pengalaman atau ilmu yang didapatkan seorang, sehingga memudahkan seorang untuk mentransfer pengetahuannya kepada siswa. Jika hal tersebut di atas bisa dilakukan dengan baik dan maksimal, maka bisa memberikan pengaruh yang positif dan signifikan bagi tingkah laku siswa.

\section{Kesimpulan}

1. Ada pengaruh yang positif dan signifikan antara kedisiplinan terhadap prestasi belajar siswa di MI se-Kecamatan Wonodadi yang ditunjukkan dari $t_{\text {hitung }}>t_{\text {tabel }}(127,173>1,968)$. Nilai signifikansi t untuk variabel kedisiplinan adalah 0.000 dan nilai tersebut lebih kecil daripada probabilitas $0.05(0,000<0,05)$. Sehingga dalam pengujian ini menunjukkan bahwa $\mathrm{H}_{\mathrm{a}}$ diterima dan $\mathrm{H}_{\mathrm{o}}$ ditolak.
Dari tabel model Summary, nilai $\mathrm{R}^{2}=0,997$ artinya variabel bebas kedisiplinan mampu menerangkan atau memprediksi nilai variabel terikat prestasi belajar siswa sebesar 99,7\%. Hal ini berarti bahwa terjadi hubungan yang rendah antara kedisiplinan terhadap prestasi belajar siswa. Serta ada pengaruh yang positif dan signifikan antara kedisiplinan $\left(\mathrm{X}_{1}\right)$ terhadap prestasi belajar siswa (Y) di MI se-Kecamatan Wonodadi.

2. Ada pengaruh yang positif dan signifikan antara motivasi belajar terhadap prestasi belajar Siswa di MI se-Kecamatan Wonodadi yang ditunjukkan dari $t_{\text {hitung }}>t_{\text {tabel }}(158,297>1,968)$. Nilai signifikansi $t$ untuk variabel pengalaman mengajar adalah 0.000 dan nilai tersebut lebih kecil daripada probabilitas $0.05(0,000<0,05)$. Sehingga dalam pengujian ini menunjukkan bahwa $\mathrm{H}_{\mathrm{a}}$ diterima dan $\mathrm{H}_{\mathrm{o}}$ ditolak. Dari tabel model Summary, nilai $\mathrm{R}^{2}=0,997$, artinya variabel bebas motivasi belajar mampu menerangkan atau memprediksi nilai variabel terikat prestasi belajar siswa sebesar 99,7\%. Hal ini berarti bahwa terjadi hubungan yang rendah antara motivasi belajar siswa terhadap prestasi belajar siswa. Serta ada pengaruh yang signifikan antara motivasi belajar $\left(\mathrm{X}_{2}\right)$ terhadap prestasi belajar siswa (Y) di MI se-Kecamatan Wonodadi.

3. Ada pengaruh yang positif dan signifikan antara kedisiplinan dan motivasi belajar terhadap prestasi belajar siswa di MI se-Kecamatan Wonodadi yang ditunjukkan dengan $\mathrm{F}_{\text {hitung }}$ $(25,514)>F_{\text {tabel }}(3,060)$. Nilai signifikansi $F$ untuk variabel kedisiplinan guru $\left(\mathrm{X}_{1}\right)$ dan motivasi belajar siswa $\left(\mathrm{X}_{2}\right)$ adalah 0.000 dan nilai tersebut lebih kecil daripada probabilitas $0.05(0,000<0,05)$. Sehingga dalam pengujian ini menunjukkan bahwa $\mathrm{H}_{\mathrm{a}}$ diterima dan $\mathrm{H}_{\mathrm{o}}$ ditolak. Hal ini berarti bahwa ada pengaruh yang positif dan signifikan antara kedisiplinan $\left(\mathrm{X}_{1}\right)$ dan motivasi belajar $\left(\mathrm{X}_{2}\right)$ terhadap prestasi belajar siswa di MI se-Kecamatan Wonodadi.

\footnotetext{
${ }^{49}$ Ibid., h. 126.
}

${ }^{50}$ Syafruddin Nurdin, et. Guru Profesional dan Implementasi Kurikulum, Cet. Ke I, (Ciputat Pers, Jakarta, 2002), h. 86. 


\section{Daftar Pustaka}

Arikunto, Suharsimi, Prosedur Penelitian Suatu Pendekatan Praktik, Jakarta: PT. Rineka Cipta, 2006.

A, Sardiman, Interaksi dan Motivasi Belajar Mengajar, Jakarta: CV. Rajawali Pers, 1990.

Bakran Adz-Dzakiey, Hamdani, Psikologi Kenabian, Yogyakarta: Al-Manar, 2008.

Bungin, Burhan, Metode Penelitian Kuantitatif, Jakarta: Prenada Media, 2005.

Departemen Agama Republik Indonesia, Al-Qur'an dan Terjemahannya, Jakarta: Duta Ilmu Surabaya, 2006.

Departemen Pendidikan dan Kebudayaan, Kamus Besar Bahasa Indonesia, Jakarta: Balai Pustaka, 1999.

D gunarsa, Singgih, Psikologi Untuk Pembimbing, Jakarta: Gunung Mulia, 2007.

Dewa Ketut Sukardi, Organisasi Administrasi Bimbingan dan konsling di Sekolah, Surabaya : Usaha Nasional, 1992

Gitosudarmo, Indriyo, Perilaku Keorganisasian, Yogyakarta: BPFE, 2001.

Hadi, Sutrisno, Metodologi Research Jilid II, Yogyakarta: Andi Offset, 1998.

Ismail Ali, Said, Pelopor Pendidikan Islam Paling Berpengaruh, Jakarta: Alkautsar, 2010.

Jauhari Muchtar, Heri, Fikih, Bandung: Remaja Rosdakarya, 2007.

J. Moleong, Lexy, Metodologi Penelitian Kualitatif, Bandung: Remaja Rosdakarya, 2002.

Karsiani, Korelasi Antara Motivasi belajar dan Lingkungan keluarga dengan Prestasi Belajar Siswa Bidang Studi PAI SMP Negeri 1 Semarang, Semarang: Universitas Negeri Semarang, 2012.

Maknun, Lukluil, Pengaruh Kedisiplinan Guru terhadap Hasil Belajar PAI Siswa Kelas VIII
SMPN 1 Sumbergempol, Tulungagung: STAIN Tulungagung, 2012.

M. Aftiyah al Abrusy, Dasar-dasar pokok Pendidikan Islam, Bandung : Al Ma'arif, 1990

M. Echols, John dan Hasan Shadily, Kamus InggrisIndonesia, Jakarta: Gramedia Pustaka Utama, 1994.

Mulyadi, Psikologi Pendidikan Biro Ilmiah, FT. IAIN Sunan Ampel, Malang, 1991.

Mulyasa, E, Standar Kompetensi dan Sertifikasi Guru, Bandung: Remaja Rosdakarya, 2007.

Nawawi, Imam, Terjemahan Riyadus Sholihin, Jilid I, Jakarta: Pustaka Amani, 1999.

Nurhasanah, Pengaruh Tingkat Intelegensi dan Motivasi Belajar Terhadap Prestasi Belajar siswa pada Mata pelajaran Matematika SMPN 1 Srengat dan SMPN 2 Srengat Tahun 2013" ,Tulungagung: STAIN Tulungagung 2013”.

Pidarta, Made, Pemikiran tentang Supervisi Pendidikan, Jakarta: Bumi Aksara, 1992.

Purwanto, Ngalim, Prinsip-Prinsip dan Teknik Evaluasi Pengajaran, Bandung: PT. Remaja Rosdakarya, 2008.

P. Siagian, Sondang, Teori Motivasi dam Aplikasinya, (Jakarta: Rineka Cipta, 1995.

Ridwan, Metode dan Teknik Menyusun Tesis, Bandung: Alfabeta, 2006.

Slamet, Belajar dan Faktor yang Mempengaruhinya, Jakarta: PT. Bina Aksara, 2003.

Soemanto, Wasty, Psikologi Pendidikan, Landasan Kerja Pemimpin Pendidikan, Jakarta: Rineka Cipta, 1990.

Sudjiono, Anas, Statistik Pendidikan, Jakarta: Raja Grafindo Persada, 1987.

Sugiyono, Dasar-Dasar Ilmu Pendidikan, Bandung: Alfabeta, 2008.

, Statistika untuk Penelitian, Bandung: Alfabeta, 2010. , Metode Penelitian Pendidikan, Bandung: Alfabeta, 2013. 
Sutrisno, Oteng, Administrasi Pendidikan Dasar Teoritis dan Praktek Professional, Bandung: Angkasa, 1985.

Suryabrata, Suryadi, Psikologi Pendidikan, Jakarta: Rajawali Press, 1993.

Tabrani Rusyan, dkk, Pendekatan dalam Proses Belajar Mengajar, Bandung: CV. Remaja Rosdkarya, 1989.

Tadjab, Ilmu Pendidikan, Surabaya: Karya Abditama, 1994.

Tanzeh, Ahmad dan Suyitno, Dasar-Dasar Penelitian, Surabaya: eLKAF, 2006.

Tanzeh, Ahmad, Metodologi Penelitian Praktis, Yogyakarta: Teras, 2011.

Triyanto, Pengaruh Motivasi Belajar dan Disiplin Sekolah terhadap Prestasi Belajar Siswa SMPN 1 Demak, Semarang: IAIN Walisongo, 2011.

Tu'u, Tulus, Peran Disiplin pada Perilaku dan Prestasi Siswa, Jakarta: PT. Raja Grafindo Persada, 2004.
Ulya, Uly, Pengaruh Minat Belajar dan Motivasi Belajar terhadap Prestasi Belajar Mata Pelajaran Fikih Siswa kelas IV dan V pada MI Riyadhlotul Ulum Kecamatan Wonodadi, (Tulungagung: STAIN Tulungagung, 2012.

Winkel, WS, Psikologi Pendidikan dan Evaluasi, Jakarta: Erlangga, 1984.

Yamin, Martinis, Profesionalisasi Guru \& Implementasi KTSP, Jakarta: Gaung Persada Press, 2011.

Ari Firmandi, "Citra Guru Indonesia", dalam http://www.citraguruindonesia.go.id, diakses 3/01/2015.

Sutrisno, "Pengertian Kedisiplinan" dalam http://starawaji.wordpress.com/2013/04/19/pen gertian-kedisiplinan, diakses 24 Januari 2016.

Tabrani, Hasbullah, Rahasia Sukses Belajar, Jakarta: Raja Grafindo Persada, 1993.

Copyright (C) 2018 Journal Dirasah: Vol. 1, No. 2, August 2018, p-ISSN: 2615-0212, e-ISSN; 26212838

Copyright rests with the authors

Copyright of Jurnal Dirasah is the property of Jurnal Dirasah and its content may not be copied or emailed to multiple sites or posted to a listserv without the copyright holder's express written permission. However, users may print, download, or email articles for individual use. https://ejournal.stisfa-kediri.ac.id/index.php/dirasah 